\title{
Article \\ The Role of Iron Carbide in the Abyssal Formation of Hydrocarbons in the Upper Mantle
}

\author{
Aleksandr Serovaiskii ${ }^{1}$ (D) and Vladimir Kutcherov ${ }^{1,2, *}$ \\ 1 Department of Physics, National University of Oil and Gas "Gubkin University", Leninsky Avenue 65/1, \\ 119991 Moscow, Russia; alexandrserov@gmail.com \\ 2 Department of Energy Technology, KTH Royal Institute of Technology, Lindstedtsvägen 30, \\ 11428 Stockholm, Sweden \\ * Correspondence: vladimir.kutcherov@energy.kth.se
}

Citation: Serovaiskii, A.; Kutcherov, V. The Role of Iron Carbide in the Abyssal Formation of Hydrocarbons in the Upper Mantle. Geosciences 2021, 11,163. https://doi.org/10.3390/ geosciences 11040163

Academic Editors:

Jesus Martinez-Frias and

Antonio Paonita

Received: 23 January 2021

Accepted: 29 March 2021

Published: 2 April 2021

Publisher's Note: MDPI stays neutral with regard to jurisdictional claims in published maps and institutional affiliations.

Copyright: (c) 2021 by the authors. Licensee MDPI, Basel, Switzerland. This article is an open access article distributed under the terms and conditions of the Creative Commons Attribution (CC BY) license (https:// creativecommons.org/licenses/by/ $4.0 /)$.

\begin{abstract}
The existence of iron carbide in the upper mantle allows an assumption to be made about its possible involvement in the abyssal abiogenic synthesis of hydrocarbons as a carbon donor. Interacting with hydrogen donors of the mantle, iron carbide can form hydrocarbon fluid. In order to investigate the role of iron carbide in the abiogenic synthesis of hydrocarbons, the chemical reaction between cementite $\mathrm{Fe}_{3} \mathrm{C}$ and water was modeled under thermobaric conditions, corresponding to the upper mantle. A series of experiments were conducted using a high-pressure high-temperature Toroid-type large reactive volume unit with further analysis by means of gas chromatography. The results demonstrated the formation of hydrocarbon fluid in a wide range of thermobaric conditions (873-1223 K, 2.5-6.0 GPa) corresponding to the upper mantle. A strong correlation between the composition of the fluid and the $\mathrm{pT}$ conditions of the synthesis was illustrated in the investigation. The higher temperature of the synthesis resulted in the formation of a "poor" hydrocarbon mixture, primarily comprising methane, while a higher pressure yielded the opposite effect, converting iron carbide into a complex hydrocarbon system, containing normal and iso-alkanes up to $C_{7}$ and benzene. This correlation explains the diversity of hydrocarbon systems produced experimentally, thus expanding the thermobaric range of the possible existence of complex hydrocarbon systems in the upper mantle. The results support the suggestion that the carbide-water reaction can be a source of both the carbon and hydrogen required for the abyssal abiogenic synthesis of hydrocarbons.
\end{abstract}

Keywords: cementite; hydrocarbons; upper mantle; high pressure; high temperature; abyssal formation of hydrocarbons

\section{Introduction}

A number of recent publications illustrate the abiogenic synthesis of complex hydrocarbon systems from inorganic substances under the thermobaric conditions of the upper mantle [1-3]. The diversity of hydrocarbon systems experimentally synthesized in the lab from inorganic compounds is not only caused by the different thermobaric parameters of the synthesis, but also by various initial donors of carbon and hydrogen in these reactions [3-5]. Calcium and magnesium carbonates, pure carbon in the form of graphite, anthracene, and carbon dioxide are associated with carbon donors for the abiogenic synthesis of hydrocarbons in the upper mantle [1]. Iron carbides were never considered carbon donors for abiogenic hydrocarbon synthesis at high pressure until recent investigations [6,7]. Sokol et al. (2020) studied the hydrogenation of Fe-Ni alloys and $\mathrm{Fe}_{3} \mathrm{C}, \mathrm{Fe}_{7} \mathrm{C}_{3}$ at $6.3 \mathrm{GPa}$ and $1000-1400{ }^{\circ} \mathrm{C}$ and demonstrated the formation of hydrocarbons primarily of $\mathrm{C}_{1}-\mathrm{C}_{4}$ composition with trace amounts of heavier hydrocarbons and oxygen-bearing substances (aldehydes, ketones, alcohols, ethers). Hydrocarbon systems synthesized from iron carbide in Reference [7] comprised hydrocarbons up to $C_{7}$ without any oxygen-bearing substances. The authors formulated a hypothesis that iron carbides 
could behave as donors of carbon in the abyssal abiogenic formation of hydrocarbons, interacting with hydrogen donors of the upper mantle $[8,9]$.

The existence of iron carbides in the mantle is supported by the detection of these compounds in diamond and garnet inclusions [10-12]. The authors detected $\mathrm{Fe}_{3} \mathrm{C}, \mathrm{Fe}_{2} \mathrm{C}$, and $\mathrm{Fe}_{23} \mathrm{C}_{6}$ in the structure of samples that were formed during subduction of the lithosphere slab. The diversity of $\mathrm{Fe}-\mathrm{C}$ inclusions demonstrates their significant role in the Earth's abyssal processes and the deep carbon cycle [13]. However, the depth range of iron carbides' existence in the mantle is still debatable. The inclusions in diamonds and garnets primarily appear to indicate the lower mantle origin of iron carbides $[10,11]$. At the same time, the possible formation of iron carbides in the upper mantle during subduction was demonstrated recently $[14,15]$. Iron carbide $\mathrm{Fe}_{7} \mathrm{C}_{3}$ was formed under thermobaric conditions corresponding to a depth of $210-290 \mathrm{~km}$ as a result of interaction between subducted hydrocarbons and the iron-bearing surrounding of the mantle. Experimental modeling of $\mathrm{Fe}-\mathrm{CaCO}_{3}$ interaction by the authors of [16] demonstrated the formation of $\mathrm{Fe}_{3} \mathrm{C}$ at $6 \mathrm{GPa}$ and $1273-1873 \mathrm{~K}$, which could act as an additional source of carbon for graphite and diamond formation in the upper mantle $[17,18]$. Experimental investigations of $\mathrm{Fe}_{3} \mathrm{C}$ melting indicated its stability in the wide range of mantle thermobaric conditions $[19,20]$. These experimental results correlate with theoretical calculations predicting the possible coexistence of diamond, graphite, and iron carbide at depths of 150-200 km and conditions close to the IW oxygen buffer [21]. Thus, iron carbide may exist in the upper mantle at a depth below $150 \mathrm{~km}$. It is expected that iron carbide as a carbon donor may interact with hydrogen donors in the upper mantle and result in the formation of hydrocarbon fluid.

The chemical reaction of iron carbide with water under high temperature has been investigated by many researchers. Akiyama, et al. [22], Hisa, et al. [23], Arabczyk, et al. [24] modeled the reaction of iron carbide and steam to produce a gas mixture with a high hydrogen concentration. This reaction was investigated under high temperature and ambient pressure. However, the pressure factor could significantly affect the mechanism and kinetics of the reaction. Thus, intermediate products could become metastable. Hydrocarbons, detected as intermediate products in [22], may become major products under extreme pressure. Moreover, heavier hydrocarbons with long carbon-carbon chains are thermodynamically more stable under high pressure, as demonstrated in $[3,25,26]$. The chemical interaction of iron carbide and water under mantle thermobaric conditions is of great interest due to its involvement in the deep processes of the Earth, such as the deep carbon cycle [13] and the deep hydrocarbon cycle [7]. This, therefore, requires detailed experimental investigation. We experimentally modeled the chemical interaction of cementite and water under a wide range of thermobaric conditions, corresponding to the Earth's upper mantle.

\section{Materials and Methods}

All experiments were conducted using the "Toroid"-type Large reactive volume (LRV) unit "URS-2" (designed and produced at the Technological Institute of super-hard and novel carbon materials, Troitsk, Russia) (See [26] for more details).

A finely ground powder of pure $\mathrm{Fe}_{3} \mathrm{C}$ (99.5\% American Elements, CAS \#12011-67-5) was mixed with distilled water and loaded into a steel cylindrical cell in the molar ratio $\mathrm{Fe}_{3} \mathrm{C}: \mathrm{H}_{2} \mathrm{O} \approx 1: 6\left(\mathrm{~m}\left(\mathrm{Fe}_{3} \mathrm{C}\right)=0.206 \mathrm{~g}, \mathrm{~m}\left(\mathrm{H}_{2} \mathrm{O}\right)=0.130 \mathrm{~g}\right)$. The cell was closed and mounted in a toroid-shaped ceramic container. The container with the cell, placed between two tungsten carbide matrices, was mounted in the LRV unit and pressurized to the required pressure. The required temperature was then reached at a speed of $100 \mathrm{~K} / \mathrm{min}$ and kept constant. The time exposure was one hour for each experiment. When the heating was over, the cell with the sample was quenched and then depressurized.

The analysis of light products was conducted by means of gas chromatography. Chromatek 5000, a gas chromatograph installed in Gubkin Russian State University of Oil and Gas, Moscow, was used to investigate the composition of light products after the experiment. The chromatograph was equipped with two columns: an Agilent GS- 
GasPro capillary column (length $60 \mathrm{~m}$, diameter $0.32 \mathrm{~mm}$ with adsorbed silica gel) and a packed column and two flame ionization detectors. The chromatograph was equipped with a special sample injection system: A sealed gas-recovering camera, connected to the chromatograph, was designed to crack the cell with the sample using a sharp, hard alloy stock penetrating the cell. After the penetration, the products were injected into the chromatograph with a carrier gas. The chromatography analysis was conducted over $60 \mathrm{~min}$. with an increasing temperature regime from 60 to $140{ }^{\circ} \mathrm{C}$.

After the chromatography analysis, the solid phase of the sample was recovered from the cell and analyzed by means of X-ray diffraction and Raman spectroscopy. A Seifert MZ III powder X-ray diffractometer, employing $\mathrm{Cu} \mathrm{K} \alpha$ radiation (1.5405981 $\AA$ wavelength) in Bragg-Brentano geometry, was used. An $\mathrm{Ar}^{+}$laser (wavelength $488 \mathrm{~nm}$, power $30 \mathrm{~mW}$ ) and a triple monochromator TriVista 555 (Princeton Instruments) equipped with a CCD detector were used in the analysis.

\section{Results}

Seven series of experiments were conducted to investigate the chemical reaction between iron carbide $\mathrm{Fe}_{3} \mathrm{C}$ and water in the thermobaric range 873-1223 $\mathrm{K}$ and 2.5-6.0 GPa. The results of the chromatography analysis of the products are presented in Table 1. Light alkanes of both a linear and branched structure and benzene were observed in the product mixtures. Unsaturated hydrocarbons (olefins and acetylene hydrocarbons) were detected at trace level (see Figure 1 for more details).

Table 1. Composition and Volume of the Product Systems Formed from $\mathrm{Fe}_{3} \mathrm{C}$ and $\mathrm{H}_{2} \mathrm{O}$ According to the Thermobaric Conditions of the Experiments.

\begin{tabular}{|c|c|c|c|c|c|c|c|c|c|c|}
\hline$\#$ & $\begin{array}{c}\text { P, GPa } \\
( \pm \mathbf{0 . 2})\end{array}$ & $\begin{array}{c}\mathrm{T}, \mathrm{K} \\
( \pm \mathbf{2 5})\end{array}$ & $\mathrm{CH}_{4}, \%$ & $\mathrm{C}_{2} \mathrm{H}_{6}, \%$ & $\mathrm{C}_{3} \mathrm{H}_{8}, \%$ & $\mathrm{C}_{4} \mathrm{H}_{10}, \%$ & $\mathrm{C}_{5} \mathrm{H}_{12}, \%$ & $\mathrm{C}_{6} \mathrm{H}_{14}, \%$ & $\mathrm{C}_{7} \mathrm{H}_{16}, \%$ & $\mathrm{C}_{6} \mathrm{H}_{6}, \%$ \\
\hline 1 & 2.5 & 873 & 81.83 & 3.10 & 1.50 & 3.51 & 3.56 & 4.03 & 0.71 & 0.70 \\
\hline 2 & 2.5 & 1023 & 96.59 & 2.01 & 0.43 & 0.32 & 0.24 & 0.25 & 0.16 & - \\
\hline 3 & 3.5 & 1023 & 87.41 & 2.33 & 0.92 & 0.48 & 2.24 & 3.26 & 2.36 & - \\
\hline 4 & 3.5 & 1123 & 79.30 & 20.38 & 0.14 & 0.04 & 0.03 & 0.03 & 0.04 & 0.01 \\
\hline 5 & 4.5 & 1123 & 84.65 & 13.89 & 0.94 & 0.30 & 0.11 & 0.07 & 0.05 & - \\
\hline 6 & 4.5 & 1223 & 98.60 & 1.32 & 0.03 & 0.03 & 0.01 & - & - & - \\
\hline 7 & 6.0 & 1223 & 68.56 & 8.96 & 7.66 & 9.27 & 4.32 & 0.98 & 0.16 & 0.09 \\
\hline 8 & $\begin{array}{r}\text { Se } \\
\text { Stavrop } \\
\text { field [4] } \\
\text { com? }\end{array}$ & $\begin{array}{l}\text { ko- } \\
\text { koe gas } \\
\text { iven for } \\
\text { ison) }\end{array}$ & 98.90 & 0.29 & 0.16 & 0.05 & - & - & - & - \\
\hline 9 & $\begin{array}{r}\text { Vuktir } \\
\text { field [4] } \\
\text { comp }\end{array}$ & $\begin{array}{l}\text { oe gas } \\
\text { iven for } \\
\text { ison) }\end{array}$ & 73.80 & 8.70 & 3.90 & 1.80 & 6.40 & - & - & - \\
\hline
\end{tabular}

As can be noted in Table 1, the composition of the hydrocarbon systems depended on the thermobaric conditions of the experiment, varying from "poor" hydrocarbon systems, similar to "dry" natural gas composition (experiments \#2 and \#6), to complex hydrocarbon systems with significant amounts of heavy hydrocarbons (experiments \#1, \#3, and \#7). Carbon dioxide and carbon monoxide were not detected in the product systems in any of the experiments.

The roles of pressure and temperature were crucial in this correlation. The increasing temperature with constant pressure resulted in the growth of the total amount of methane and ethane in the product system: \#1 and \#2 at $2.5 \mathrm{GPa}$, \#3 and \#4 at $3.5 \mathrm{GPa}$, \#5 and \#6 at $4.5 \mathrm{GPa}$. At the same time, the increasing pressure with constant temperature enhanced the yield of the $C_{3+}$ fraction: (\#2 and $\# 3$ at $1023 \mathrm{~K}, \# 4$ and $\# 5$ at $1123 \mathrm{~K}$, \#6 and $\# 7$ at $1223 \mathrm{~K}$ ). The specified correlation is more recognizable in Figure 2, in which the results are grouped and the relative content of fractions in the hydrocarbon fluid is presented as pie charts. 

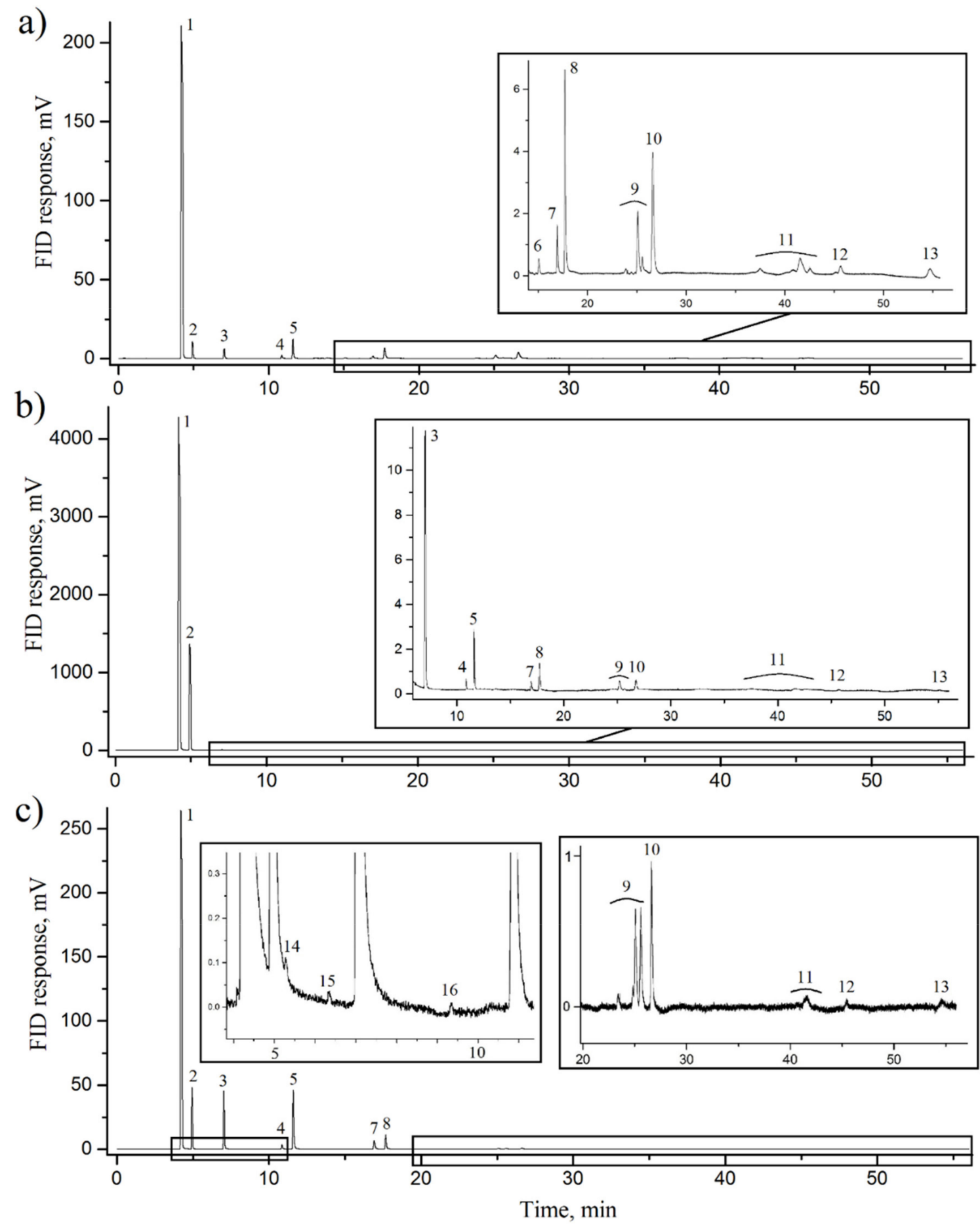

Figure 1. The chromatograms of hydrocarbon products formed from the chemical reaction of iron carbide and water at (a) $2.5 \mathrm{GPa}$ and $873 \mathrm{~K}$; (b) $3.5 \mathrm{GPa}$ and $1123 \mathrm{~K}$; (c) $6.0 \mathrm{GPa}$ and $1223 \mathrm{~K} .1$-methane, 2-ethane, 3-propane, 4-i-butane, 5-n-butane, 6-neo-pentane; 7-i-pentane, 8-n-pentane, 9-i-hexanes, 10-n-hexane, 11-i-heptanes, 12-n-heptane, 13-benzene, 14-ethylene, 15-acetylene, 16-propylene. 


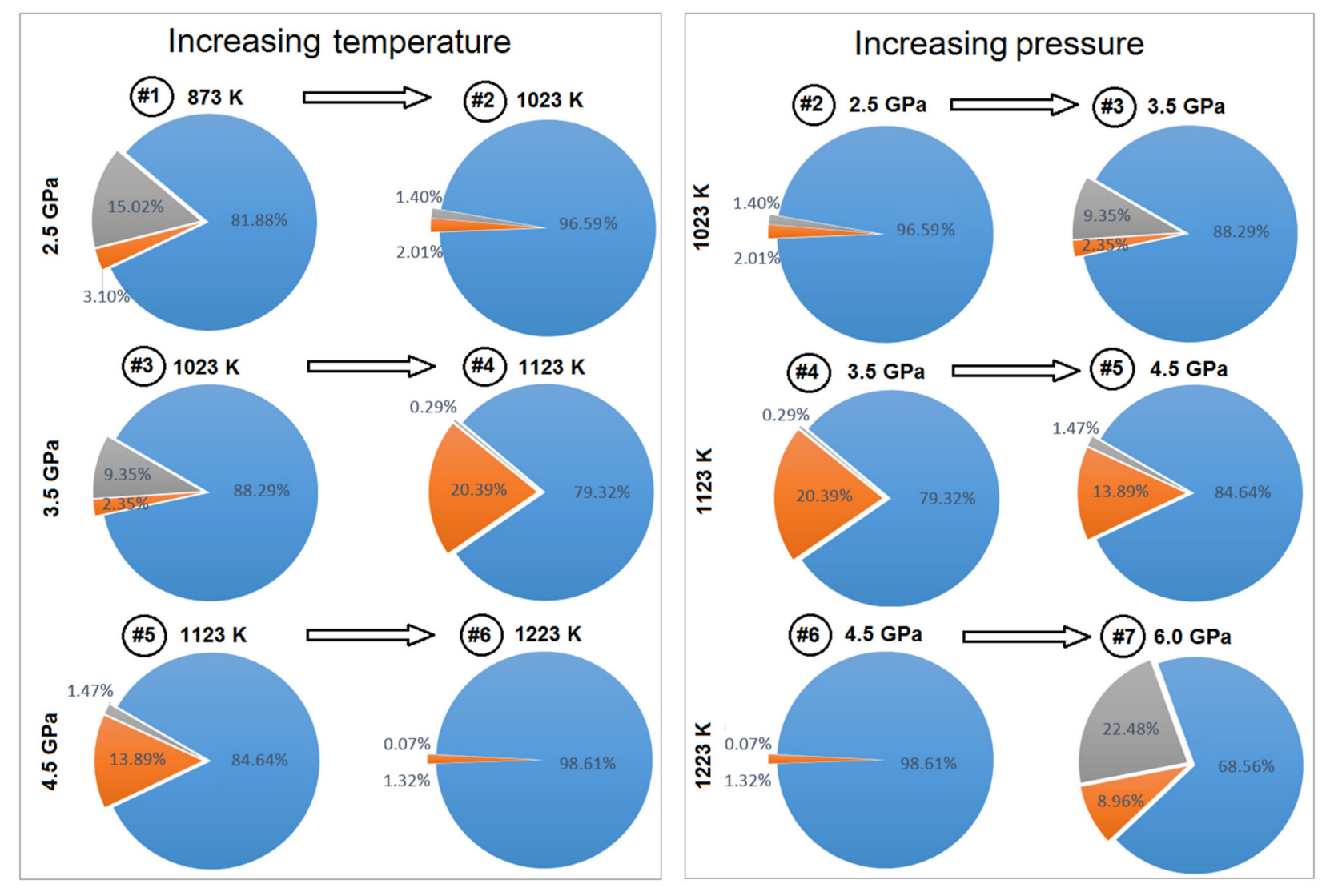

Figure 2. Pie charts of hydrocarbon products, formed from the chemical reaction of iron carbide and water. Blue sectors$\mathrm{CH}_{4}$, orange sectors $-\mathrm{C}_{2} \mathrm{H}_{6}$, grey sectors-total amount of heavier hydrocarbons $\mathrm{C}_{3+}$.

The results of the solid product analysis are presented in Table 2.

Table 2. Results of the Analysis of the Solid Products Formed from $\mathrm{Fe}_{3} \mathrm{C}$ and $\mathrm{H}_{2} \mathrm{O}$.

\begin{tabular}{ccccc}
\hline$\#$ & $\mathbf{P}, \mathbf{G P a}( \pm \mathbf{0 . 2 )}$ & $\mathbf{T , K ~}( \pm \mathbf{2 5})$ & X-ray Diffraction & Raman Spectroscopy \\
\hline 1 & 2.5 & 873 & Remained $\mathrm{Fe}_{3} \mathrm{C}$, no new & compounds \\
2 & 2.5 & 1023 & Remained $\mathrm{Fe}_{3} \mathrm{C}, \mathrm{FeO}$ & $\mathrm{Fe}_{3} \mathrm{O}_{4}$ \\
3 & 3.5 & 1023 & Remained $\mathrm{Fe}_{3} \mathrm{C}, \mathrm{FeO}$ & $\mathrm{Fe}_{3} \mathrm{O}_{4}, \mathrm{FeO}$ \\
4 & 3.5 & 1123 & Ro new compounds \\
5 & 4.5 & 1123 & Remained $\mathrm{Fe}_{3} \mathrm{C}, \mathrm{FeO}$ & - \\
6 & 4.5 & 1223 & Remained $\mathrm{Fe}_{3} \mathrm{C}, \mathrm{FeO}$ & No new compounds \\
7 & 6.0 & 1223 & - & - \\
\hline
\end{tabular}

$X$-ray diffraction of the solid products formed from the chemical reaction of iron carbide and water demonstrated the formation of $\mathrm{FeO}$ in experiments \#2, \#3, \#4, \#5, and \#6 (Figure 3). Characteristic peaks (111), (200), (220), (311), and (222), detected in the $X$-ray spectra, correspond to wüstite [27]. X-ray spectrum \#1 showed only representative peaks of $\mathrm{Fe}_{3} \mathrm{C}$, like in the reference spectrum 0, collected from initial $\mathrm{Fe}_{3} \mathrm{C}$ before the experiments [28]. 


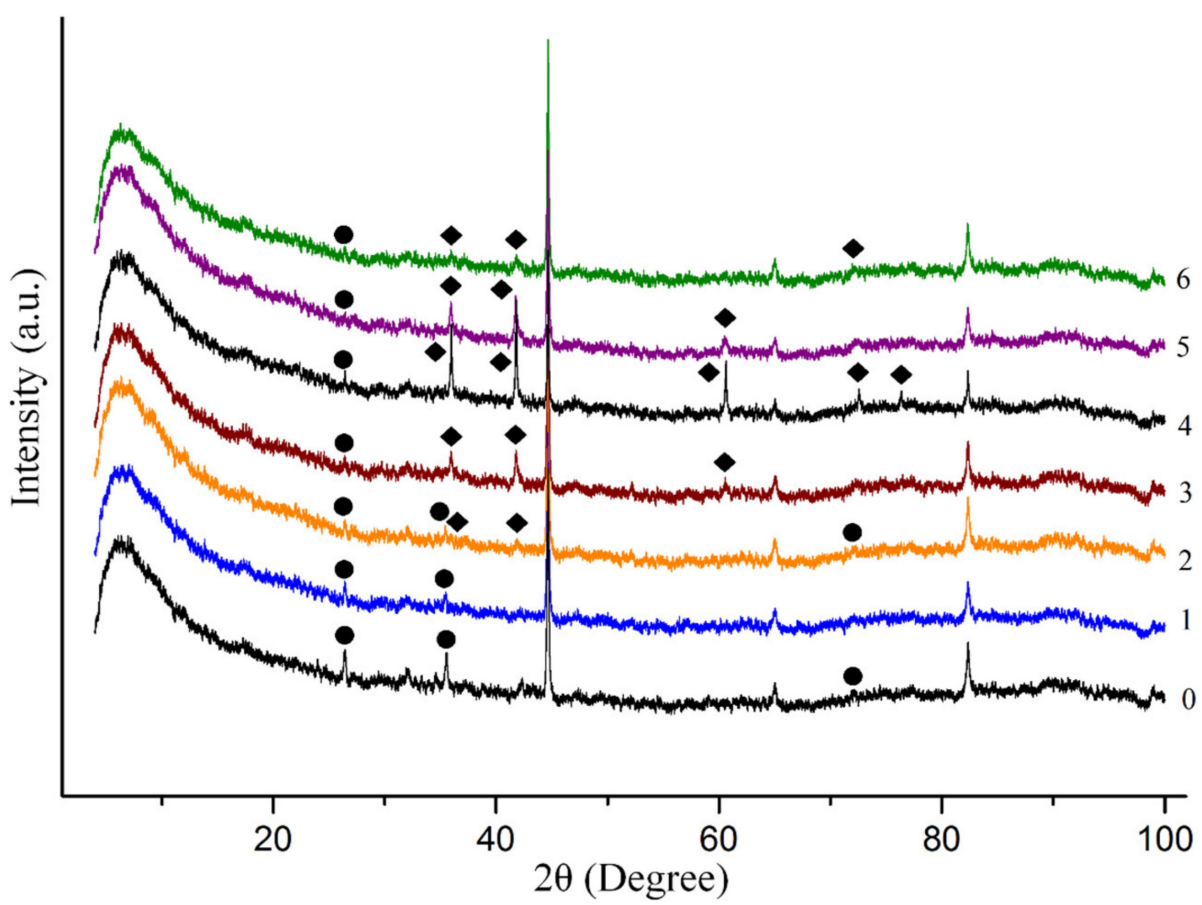

Figure 3. XRD patterns of the samples: 0 - pure iron carbide $\mathrm{Fe}_{3} \mathrm{C}$ before reaction [28]; 1-6-solid products of the chemical reaction between $\mathrm{Fe}_{3} \mathrm{C}$ and $\mathrm{H}_{2} \mathrm{O}$ : at $873 \mathrm{~K}$ and $2.5 \mathrm{GPa}$ (exp. \#1), at $1023 \mathrm{~K}$ and 2.5 GPa (exp. \#2), at $1023 \mathrm{~K}$ and $3.5 \mathrm{GPa}$ (exp. \#3), at $1123 \mathrm{~K}$ and $3.5 \mathrm{GPa}$ (exp. \#4), at $1123 \mathrm{~K}$ and $4.5 \mathrm{GPa}$ (exp. \#5), at $1223 \mathrm{~K}$ and $4.5 \mathrm{GPa}$ (exp. \#6); circles-characteristic peaks of $\mathrm{Fe}_{3} \mathrm{C}$, diamonds—characteristic peaks of FeO.

The Raman spectroscopy analysis in experiment \#1 showed strong wave shifts at 548 and $678 \mathrm{~cm}^{-1}$, corresponding to $\mathrm{Fe}_{3} \mathrm{O}_{4}$ [29], while the Raman spectrum of experiment \#2 was complicated and could be interpreted as a combination of Raman shifts of $\mathrm{Fe}_{3} \mathrm{O}_{4}$ and $\mathrm{FeO}$, according to reference data from the literature (Figure 4) [30-32]. The Raman spectra of the solid products of experiments \#3 and \#5 demonstrated only the wave shifts of the initial iron carbide.

It was not possible to observe $\mathrm{Fe}_{3} \mathrm{O}_{4}$ using X-ray diffraction due to its weak characteristic peaks on the diffraction spectra [33]. FeO was not detected using Raman spectroscopy in experiments \#3 and \#5. This could be due to a low concentration of the substance and the low resolution of the Raman spectrometer. Graphite was not observed using Raman and X-ray spectroscopies. 


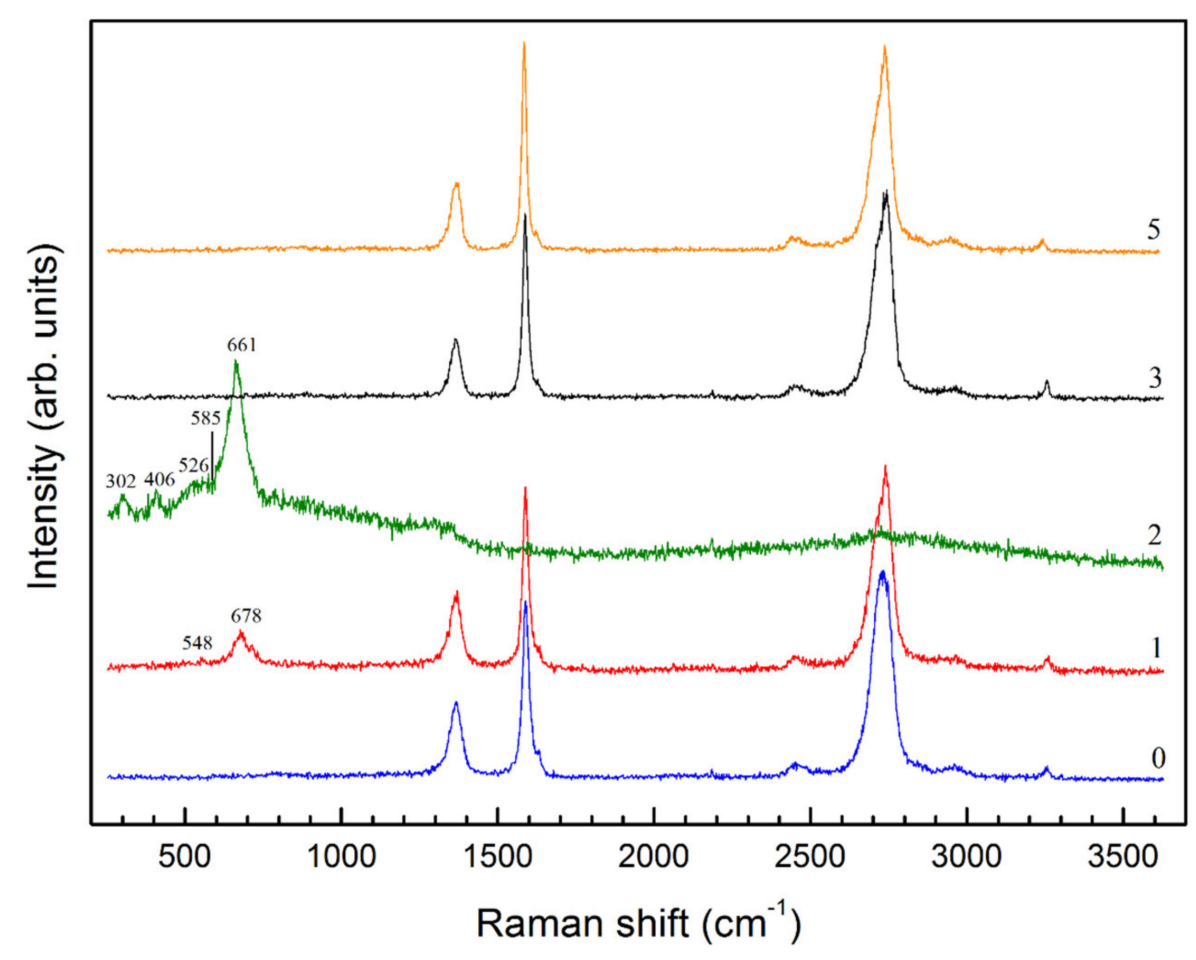

Figure 4. The Raman spectra of the samples: 0-pure iron carbide $\mathrm{Fe}_{3} \mathrm{C} ; 1$-5-solid products of the chemical reaction between $\mathrm{Fe}_{3} \mathrm{C}$ and $\mathrm{H}_{2} \mathrm{O}$ : at $873 \mathrm{~K}$ and $2.5 \mathrm{GPa}$ (exp. \#1); at $1023 \mathrm{~K}$ and $2.5 \mathrm{GPa}$ (exp. \#2), at $1023 \mathrm{~K}$ and $3.5 \mathrm{GPa}$ (exp. \#3), at $1123 \mathrm{~K}$ and $4.5 \mathrm{GPa}$ (exp. \#5).

\section{Discussion}

4.1. Iron Carbide as a Possible Donor of Carbon in the Abiogenic Synthesis of Hydrocarbons in the Upper Mantle. The Influence of $\mathrm{T}$ T Conditions of the Upper Mantle on the Composition of Hydrocarbon Fluid

The results of the current investigation highlighted the possible abiogenic formation of complex hydrocarbon mixtures from iron carbide and water in the wide range of thermobaric conditions 2.5-6.0 GPa and 673-1223 K, which correspond to the depths of $80-180 \mathrm{~km}$ of the cold zones of the mantle [34]. As expected, the chemical reaction of cementite and water under ultra-high $\mathrm{pT}$ conditions caused the formation of hydrocarbon fluid of a composition similar to previous researches with the other carbon donors $[3,35]$. The total amount of light hydrocarbons dominated the product systems (methane-6999 volume $\%$, ethane-1-20 volume\%), while the content of heavier hydrocarbons $\left(C_{3+}\right)$ varied depending on the $\mathrm{pT}$ conditions of the reaction. These data demonstrate that iron carbide may be a carbon donor in the abyssal abiogenic synthesis of hydrocarbons in the upper mantle at depths of $80-180 \mathrm{~km}$ (Figure 5). The influence of the thermobaric parameters was complicated by the opposite effects of pressure and temperature. The higher temperature resulted in the formation of hydrocarbon fluid comprising methane and ethane with a trace amount of heavier hydrocarbons, while the higher temperature brought the synthesis of hydrocarbon fluid containing significant amounts of heavier hydrocarbons $\mathrm{C}_{3}-\mathrm{C}_{7}$. This correlation is discernible in the investigation of methane transformation at $2.5 \mathrm{GPa}$ and $850-1000 \mathrm{~K}$ [26]. The hydrocarbon system synthesized from methane at a more moderate temperature contained heavy hydrocarbons up to $C_{7}$, while the hydrocarbon system formed at $1000 \mathrm{~K}$ was limited to $\mathrm{C}_{4}-\mathrm{C}_{6}$ components with a significant predominance of methane and ethane. 


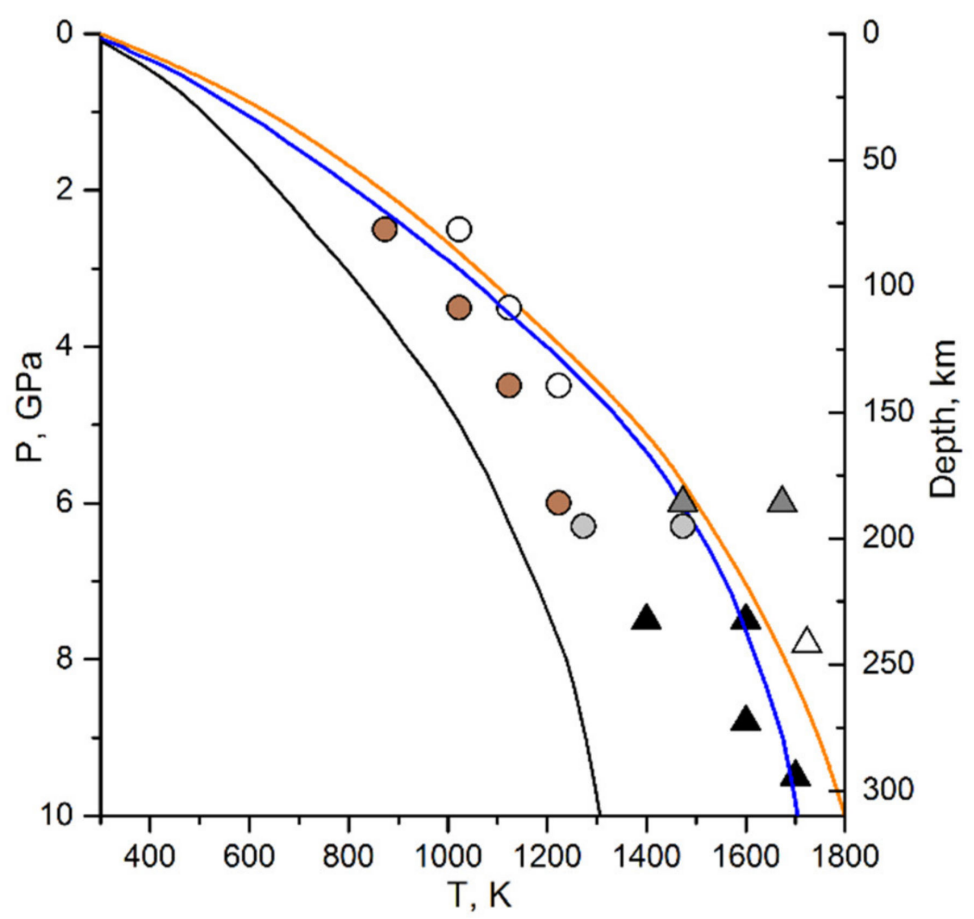

Figure 5. Experimental evidence of iron carbide formation (triangles) under the mantle pT conditions and hydrocarbon formation (circles) from iron carbide under the mantle pT conditions: Black triangles-experiments from [15], empty triangles-experiments from [2], grey trianglesexperiments from [16], grey circles—experiments from [5], white circles— "poor" hydrocarbon systems, current research, brown circles- "rich" hydrocarbon systems, current research. Pressuretemperature profiles of the Earth's geotherms (black curve- $30 \mathrm{~mW} / \mathrm{m}^{2}$ continental geotherm, blue curve $-40 \mathrm{~mW} / \mathrm{m}^{2}$ continental geotherm, orange curve $-40 \mathrm{~mW} / \mathrm{m}^{2}$ ocean geotherm) are taken from Reference [34].

The correlation between the composition of the hydrocarbon system and the thermobaric conditions of the experiment can be observed in the experiments with $\mathrm{CaCO}_{3}$ as a donor of hydrocarbons. The hydrocarbon system synthesized from $\mathrm{CaCO}_{3}$ and water in the presence of iron compounds at $5 \mathrm{GPa}$ and $1473 \mathrm{~K}$ using a CONAC high-pressure chamber [3] contained around $94 \%$ methane and around 3\% ethane/ethylene. The total amount of heavier hydrocarbons did not exceed $3 \%$ and was limited by trace amounts of $\mathrm{C}_{5}$ and $\mathrm{C} 6$ hydrocarbons. The hydrocarbon systems synthesized from $\mathrm{CaCO}_{3}$ and water under more moderate $\mathrm{pT}$ conditions [36] contained heavier hydrocarbons (up to $\mathrm{C}_{7}$ ). Mukhina, Kolesnikov, and Kutcherov [36] did not provide the quantitative composition of gaseous products. However, the presented chromatograms reflected the broad variety of isomers of heavy hydrocarbons and demonstrated a substantial total amount of $C_{3+}$ hydrocarbons.

Due to the proximity to thermobaric conditions, the composition of hydrocarbon mixtures synthesized from $\mathrm{CaCO}_{3}$ and water [3] may be compared with the results of experiment \#6 in the current research: The methane-ethane heavier HC ratio slightly differs, while the composition of heavier hydrocarbons is also limited by $\mathrm{C}_{5}$ components. At the same moment, the hydrocarbon systems \#1 and \#2 described in [36] are very close to system \#1 in the current research. The intensity of the chromatogram peaks of heavy hydrocarbons in reference to the methane peak indicates an amount of heavy hydrocarbons similar to the experiments in the current investigation. Essentially, the chromatogram of experiment \#2 described in [36] is close to the chromatogram of hydrocarbon products formed in experiment \#1 (Figure 1). Regardless of the initial carbon compounds $\left(\mathrm{CaCO}_{3}\right.$ vs. $\mathrm{Fe}_{3} \mathrm{C}$ ), the composition of the hydrocarbon system is largely the same. Thus, the thermobaric conditions of the synthesis are the crucial factor. In contrast, the different 
levels of oxygen fugacity (IW buffer vs. Iron) do not provide a significant effect on the chemistry of the reaction [37], however, they may influence the yield of hydrocarbons in the product system [5].

There are obviously no grounds for reaching a conclusion about the linearity between the thermobaric parameters and the composition of hydrocarbon fluid due to uncertainties in pressure and temperature measurement. Moreover, the effect of pressure and temperature on the relative distribution of individual isomers of heavy hydrocarbons is not yet clear due to low concentrations. However, the existence of hydrocarbon fluid containing heavy hydrocarbons in the upper mantle is now clear. Longer exposure time and smaller pressure and temperature increments in the experiments may provide further information about these correlations in the future.

\subsection{Chemical Mechanisms of the Formation of Hydrocarbons from Iron Carbide}

The possibility of hydrocarbon formation from iron carbide was first mentioned by the authors of [22] during an investigation of hydrogen generation from iron carbide and steam under ambient pressure and temperature up to $1373 \mathrm{~K}$. Hydrocarbons $\left(\mathrm{CH}_{4}\right.$ and $\mathrm{C}_{2} \mathrm{H}_{6}$ ) were detected at trace level during the second stage of hydrogen synthesis in the temperature range $873-993 \mathrm{~K}$. These substances appeared to be unwanted products formed as a result of the interaction of carbon monoxide and hydrogen. Hydrocarbons were transformed into carbon dioxide during the third stage of the synthesis (993-1373 K), while hydrogen was the predominant reaction product.

The second stage of the process of hydrogen formation from iron carbide and steam under ambient pressure and high temperature experimentally confirms the ideas about the mechanism of abiogenic hydrocarbon formation [38,39]. The synthesis of complex hydrocarbon systems from donors of carbon and hydrogen proceeds through the formation of methane from carbon oxides and molecular hydrogen, the so-called Fischer-Tropsch type reaction [40]. This mechanism appears to be relevant for the formation of light hydrocarbons (mostly methane and ethane) from iron carbide under extreme thermobaric conditions. The formation of heavier hydrocarbons follows the growth of the carbon-carbon bonds via a radical mechanism [41]. A significant increase in pressure (up to several GPa) enhances the formation of hydrocarbons due to Le Chatelier's principle. Thus, the higher pressure leads to heavier hydrocarbons in the system [42]. The chemical pathways of heavier hydrocarbon formation appear to be similar to those described in [26]. The synthesis of heavier hydrocarbons of both a normal and branched structure from lighter hydrocarbons is accompanied by simultaneous isomerization and cyclization. However, hydrocarbons of a cyclic structure were only presented by benzene in the system. Naphthenes were not detected in the product systems that might be explained by low concentrations of these compounds.

\subsection{Oxidation of Iron Compounds in the Abiogenic Synthesis of Hydrocarbons}

The formation of hydrocarbons from inorganic substances in the upper mantle is indispensably accompanied by the transformation of iron into oxidized forms: $\mathrm{FeO}, \mathrm{Fe}_{3} \mathrm{O}_{4}$, or $\mathrm{Fe}_{2} \mathrm{O}_{3}[4,25,37,38,43]$, while $\mathrm{FeO}$ is preferable under higher pressures [43]. In the current investigation, $\mathrm{Fe}_{3} \mathrm{O}_{4}$ was observed in experiments at a pressure of $2.5 \mathrm{GPa}$ (exp. \#1 and \#2), while FeO was detected at 2.5-4.5 GPa (experiments \#2, \#3, \#4, \#5, \#6). The higher temperature at $2.5 \mathrm{GPa}$ in exp. $\# 2$ resulted in a reduction of most $\mathrm{Fe}_{3} \mathrm{O}_{4}$ through its reaction with hydrogen or hydrocarbons in the system as a reversed process described in [43]:

$$
\mathrm{Fe}_{3} \mathrm{O}_{4}+\mathrm{H}_{2} \rightarrow 3 \mathrm{FeO}+\mathrm{H}_{2} \mathrm{O}
$$

An alternative explanation was the possible formation of $\mathrm{Fe}_{3} \mathrm{O}_{4}$ as a non-equilibrium product in the experiments at $2.5 \mathrm{GPa}$ and $873-1023 \mathrm{~K}$, while its formation was impossible at higher temperatures when the system more rapidly equilibrated. 


\section{Conclusions}

The experimental results describe the formation of hydrocarbon fluid in the $\mathrm{Fe}_{3} \mathrm{C}$ $\mathrm{H}_{2} \mathrm{O}$ system under a wide range of thermobaric conditions corresponding to depths of $80-180 \mathrm{~km}$. It is possible to suggest the following pathway of the reaction:

$$
\mathrm{Fe}_{3} \mathrm{C}+\mathrm{H}_{2} \mathrm{O} \rightarrow \mathrm{FeO} / \mathrm{Fe}_{3} \mathrm{O}_{4}+\mathrm{C}_{\mathrm{n}} \mathrm{H}_{2 \mathrm{n}+2}+\mathrm{C}_{\mathrm{m}} \mathrm{H}_{2 \mathrm{~m}}
$$

The synthesized hydrocarbon systems comprise normal and branched alkanes and benzene. Unsaturated hydrocarbons (ethylenes and acetylenes) detected at the trace level appear to be intermediate products of the reaction, thereby demonstrating the radical chemical pathway of the growth of carbon-carbon chains of the products. The fraction composition correlates with the pressure and temperature of the reaction: the yield of heavier hydrocarbons increases under higher pressure and constant temperature, while higher temperature and constant pressure enhance the amount of light components. This correlation provides insight into the composition of hydrocarbon fluid in different zones of the mantle at depths of 80-180 km (Figure 5). Complex hydrocarbon systems with a relatively high content of heavier hydrocarbons ("rich" systems), close to "wet" natural gas or gas condensate, are relevant to colder zones of the upper mantle. Hydrocarbon fluid, the composition of which corresponds to "dry" (methane-rich) natural gas, dominates in hotter regions of the mantle [44].

The experimental results presented in this paper broaden the knowledge of the formation of hydrocarbon fluid in the upper mantle and explicate the upward flow of the deep hydrocarbon cycle [7]. Iron carbide presented in the deep Earth's interior or generated during subduction may serve as a donor of carbon for the abyssal abiogenic synthesis of hydrocarbons. The generated hydrocarbon fluid could migrate upwards to the Earth's crust within the mantle plume [45], volcanic activity [46], or along a weakened surface of the subducted slab [36].

Author Contributions: V.K. and A.S. designed the study. A.S. carried out the experiments and analyzed the data. A.S. and V.K. discussed the results and wrote the manuscript. Conceptualization, A.S., V.K.; methodology, A.S., V.K.; formal analysis, A.S.; investigation, A.S.; writing—original draft preparation, A.S., V.K.; writing—review and editing, A.S., V.K.; supervision, V.K.; project administration, A.S.; funding acquisition, A.S., V.K. All authors have read and agreed to the published version of the manuscript.

Funding: This research was funded by Russian Science Foundation (project number 20-77-00078).

Institutional Review Board Statement: Not applicable.

Informed Consent Statement: Not applicable.

Data Availability Statement: The data presented in this study are available on request from the corresponding author.

Acknowledgments: We would like to thank V. Brazhkin, I. Zibrov, and S. Lyapin (Institute for High Pressure Physics, Russian Academy of Sciences) for their help in organizing and performing Raman spectroscopy and X-ray diffraction analysis.

Conflicts of Interest: The authors declare no conflict of interest. The funders had no role in the design of the study; in the collection, analyses, or interpretation of data; in the writing of the manuscript, or in the decision to publish the results.

\section{References}

1. Kolesnikov, A.Y.; Saul, J.M.; Kutcherov, V.G. Chemistry of hydrocarbons under extreme thermobaric conditions. Chem. Sel. 2017, 2, 1336-1352. [CrossRef]

2. Sokol, A.G.; Tomilenko, A.A.; Bul'bak, T.A.; Sobolev, N.V. Synthesis of hydrocarbons by $\mathrm{CO}_{2}$ fluid conversion with hydrogen: Experimental modeling at $7.8 \mathrm{GPa}$ and $1350^{\circ} \mathrm{C}$. Dokl. Earth Sci. 2017, 477, 1483-1487. [CrossRef]

3. Kutcherov, V.G.; Bendeliani, N.A.; Alekseev, V.A.; Kenney, J.F. Synthesis of hydrocarbons from minerals at pressures up to 5 GPa. Dokl. Phys. Chem. 2002, 387, 328-330. [CrossRef] 
4. Kutcherov, V.G.; Kolesnikov, A.; Dyugheva, T.I.; Kulikova, L.F.; Nikolaev, N.N.; Sazanova, O.A.; Braghkin, V.V. Synthesis of complex hydrocarbon systems at temperatures and pressures corresponding to the Earth's upper mantle conditions. Dokl. Phys. Chem. 2010, 433, 132-135. [CrossRef]

5. Sokol, A.G.; Tomilenko, A.A.; Bul'bak, T.A.; Sokol, I.A.; Zaikin, P.A.; Palyanova, G.A.; Palyanov, Y.N. Hydrogenation of carbon at 5.5-7.8 GPa and $1100-1400{ }^{\circ} \mathrm{C}$ : Implications to formation of hydrocarbons in reduced mantles of terrestrial planets. Phys. Earth Planet. Inter. 2019, 291, 12-23. [CrossRef]

6. Sokol, A.; Tomilenko, A.; Sokol, I.; Zaikin, P.; Bul'bak, T. Formation of hydrocarbons in the presence of native iron under upper mantle conditions: Experimental constraints. Minerals 2020, 10, 88. [CrossRef]

7. Kutcherov, V.; Ivanov, K.; Mukhina, E.; Serovaiskii, A. Deep hydrocarbon cycle. Carbon Earth Inter. 2020. [CrossRef]

8. Bell, D.R.; Rossman, G.R. Water in Earth's Mantle: The role of nominally anhydrous minerals. Science 1992, 255, 1391. [CrossRef]

9. Ohtani, E. Water in the mantle. Elements 2005, 1, 25-30. [CrossRef]

10. Kaminsky, F.V.; Wirth, R. Iron carbide inclusions in lower-mantle diamond from Juina, Brazil. Can. Mineral. 2011, 49, 555-572. [CrossRef]

11. Jacob, D.E.; Kronz, A.; Viljoen, K.S. Cohenite, native iron and troilite inclusions in garnets from polycrystalline diamond aggregates. Contrib. Mineral. Petrol. 2004, 146, 566-576. [CrossRef]

12. Shatsky, V.S.; Ragozin, A.L.; Logvinova, A.M.; Wirth, R.; Kalinina, V.V.; Sobolev, N.V. Diamond-rich placer deposits from iron-saturated mantle beneath the northeastern margin of the Siberian Craton. Lithos 2020, 364-365, 105514. [CrossRef]

13. Dasgupta, R.; Hirschmann, M.M. The deep carbon cycle and melting in Earth's interior. Earth Planet. Sci. Lett. 2010, $298,1-13$. [CrossRef]

14. Serovaiskii, A.Y.; Kolesnikov, A.Y.; Kutcherov, V.G. Formation of iron hydride and iron carbide from hydrocarbon systems at ultra-high thermobaric conditions. Geochem. Int. 2019, 57, 1008-1014. [CrossRef]

15. Serovaiskii, A.; Mukhina, E.; Dubrovinsky, L.; Chernoutsan, A.; Kudryavtsev, D.; McCammon, C.; Aprilis, G.; Kupenko, I.; Chumakov, A.; Hanfland, M.; et al. Fate of hydrocarbons in iron-bearing mineral environments during subduction. Minerals 2019, 9, 651. [CrossRef]

16. Martirosyan, N.S.; Litasov, K.D.; Shatskiy, A.; Ohtani, E. The reactions between iron and magnesite at 6 GPa and $1273-1873$ K Implication to reduction of subducted carbonate in the deep mantle. J. Mineral. Petrol. Sci. 2015, 110, 49-59. [CrossRef]

17. Bataleva, Y.V.; Palyanov, Y.N.; Borzdov, Y.M.; Bayukov, O.A.; Zdrokov, E.V. Iron carbide as a source of carbon for graphite and diamond formation under lithospheric mantle P-T parameters. Lithos 2017, 286-287, 151-161. [CrossRef]

18. Bataleva, Y.V.; Palyanov, Y.N.; Borzdov, Y.M.; Bayukov, O.A.; Sobolev, N.V. Conditions for diamond and graphite formation from iron carbide at the PT parameters of lithospheric mantle. Russ. Geol. Geophys. 2016, 57, 176-189. [CrossRef]

19. Lord, O.T.; Walter, M.J.; Dasgupta, R.; Walker, D.; Clark, S.M. Melting in the Fe-C system to 70 GPa. Earth Planet. Sci. Lett. 2009, 284, 157-167. [CrossRef]

20. Rohrbach, A.; Ghosh, S.; Schmidt, M.W.; Wijbrans, C.H.; Klemme, S. The stability of Fe-Ni carbides in the Earth's mantle: Evidence for a low Fe-Ni-C melt fraction in the deep mantle. Earth Planet. Sci. Lett. 2014, 388, 211-221. [CrossRef]

21. Stagno, V.; Frost, D.J. Carbon speciation in the asthenosphere: Experimental measurements of the redox conditions at which carbonate-bearing melts coexist with graphite or diamond in peridotite assemblages. Earth Planet. Sci. Lett. 2010, 300, 72-84. [CrossRef]

22. Akiyama, T.; Miyazaki, A.; Nakanishi, H.; Hisa, M.; Tsutsumi, A. Thermal and gas analyses of the reaction between iron carbide and steam with hydrogen generation at 573K. Int. J. Hydrogen Energy 2004, 29, 721-724. [CrossRef]

23. Hisa, M.; Tsutsumi, A.; Akiyama, T. Materialographic investigation on the mechanism of hydrogen production through the reaction between iron carbide and steam at a temperature of $673 \mathrm{~K}$. Mater. Trans. 2004, 45, 1911-1914. [CrossRef]

24. Arabczyk, W.; Ekiert, E.; Jesdrzejewski, R. Kinetics of the oxidation of iron carbide dispersed in a carbon matrix with water vapor. J. Phys. Chem. A 2009, 113, 4947-4953. [CrossRef] [PubMed]

25. Sonin, V.M.; Bul'bak, T.A.; Zhimulev, E.I.; Tomilenko, A.A.; Chepurov, A.I.; Pokhilenko, N.P. Synthesis of heavy hydrocarbons under P-T conditions of the Earth's upper mantle. Dokl. Earth Sci. 2014, 454, 32-36. [CrossRef]

26. Serovaiskii, A.; Kutcherov, V. Formation of complex hydrocarbon systems from methane at the upper mantle thermobaric conditions. Sci. Rep. 2020, 10, 4559. [CrossRef]

27. Khurshid, H.; Li, W.; Chandra, S.; Phan, M.-H.; Hadjipanayis, G.C.; Mukherjee, P.; Srikanth, H. Mechanism and controlled growth of shape and size variant core/shell $\mathrm{FeO} / \mathrm{Fe}_{3} \mathrm{O}_{4}$ nanoparticles. Nanoscale 2013, 5, 7942-7952. [CrossRef]

28. Kumari, R.; Krishnia, L.; Kumar, V.; Singh, S.; Singh, H.K.; Kotnala, R.K.; Juluri, R.R.; Bhatta, U.M.; Satyam, P.V.; Yadav, B.S. $\mathrm{Fe}_{3} \mathrm{C}$-filled carbon nanotubes: Permanent cylindrical nanomagnets possessing exotic magnetic properties. Nanoscale 2016, 8 , 4299-4310. [CrossRef]

29. De Faria, D.L.A.; Venâncio Silva, S.; De Oliveira, M.T. Raman microspectroscopy of some iron oxides and oxyhydroxides. J. Raman Spectrosc. 1997, 28, 873-878. [CrossRef]

30. Mouayd, A.A.; Koltsov, A.; Sutter, E.; Tribollet, B. Effect of silicon content in steel and oxidation temperature on scale growth and morphology. Mater. Chem. Phys. 2014, 143, 996-1004. [CrossRef]

31. Martin, A.M.; Righter, K. Melting of clinopyroxene+ magnesite in iron-bearing planetary mantles and implications for the Earth and Mars. Contrib. Mineral. Petrol. 2013, 166, 1067-1098. [CrossRef] 
32. Ishizaka, K.; Lewis, S.R.; Hammond, D.; Lewis, R. Chemistry of black leaf films synthesised using rail steels and their influence on the low friction mechanism. RSC Adv. 2018, 8, 32506-32521. [CrossRef]

33. Williams, B.; Clifford, D.; El-Gendy, A.A.; Carpenter, E.E. Solvothermal synthesis of $\mathrm{Fe}_{7} \mathrm{C}_{3}$ and $\mathrm{Fe}_{3} \mathrm{C}$ nanostructures with phase and morphology control. J. Appl. Phys. 2016, 120, 033904. [CrossRef]

34. Pollack, H.N.; Chapman, D.S. On the regional variation of heat flow, geotherms, and lithospheric thickness. Tectonophysics 1977, 38, 279-296. [CrossRef]

35. Kutcherov, V.G.; Krayushkin, V.A. Deep-seated abiogenic origin of petroleum: From geological assessment to physical theory. Rev. Geophys. 2010, 48, 1-30. [CrossRef]

36. Mukhina, E.; Kolesnikov, A.; Kutcherov, V. The lower pT limit of deep hydrocarbon synthesis by $\mathrm{CaCO}_{3}$ aqueous reduction. Sci. Rep. 2017, 7, 5749. [CrossRef]

37. Kolesnikov, A.; Kutcherov, V.G.; Goncharov, A.F. Methane-derived hydrocarbons produced under upper-mantle conditions. Nat. Geosci. 2009, 2, 566-570. [CrossRef]

38. Chen, J.Y.; Jin, L.J.; Dong, J.P.; Zheng, H.F.; Liu, G.Y. Methane formation from $\mathrm{CaCO}_{3}$ reduction catalyzed by high pressure. Chin. Chem. Lett. 2008, 19, 475-478. [CrossRef]

39. Sharma, A.; Cody, G.D.; Hemley, R.J. In situ diamond-anvil cell observations of methanogenesis at high pressures and temperatures. Energy Fuel 2009, 23, 5571-5579. [CrossRef]

40. Kenney, J.F.; Kutcherov, V.A.; Bendeliani, N.A.; Alekseev, V.A. The evolution of multicomponent systems at high pressures: VI. The thermodynamic stability of the hydrogen-carbon system: The genesis of hydrocarbons and the origin of petroleum. Proc. Natl. Acad. Sci. USA 2002, 99, 10976-10981. [CrossRef]

41. Dominé, F.; Bounaceur, R.; Scacchi, G.; Marquaire, P.-M.; Dessort, D.; Pradier, B.; Brevart, O. Up to what temperature is petroleum stable? New insights from a 5200 free radical reactions model. Org. Geochem. 2002, 33, 1487-1499. [CrossRef]

42. Dominé, F. High pressure pyrolysis of n-hexane, 2,4-dimethylpentane and 1-phenylbutane. Is pressure an important geochemical parameter? Org. Geochem. 1991, 17, 619-634. [CrossRef]

43. Scott, H.P.; Hemley, R.J.; Mao, H.-k.; Herschbach, D.R.; Fried, L.E.; Howard, W.M. Generation of methane in the Earth's mantle: In situ high pressure-temperature measurements of carbonate reduction. PNAS 2004, 101, 14023-14026. [CrossRef]

44. Vyakhirev, R.I.K.; Yu, P.; Kabanov, N.I. Teoriya i Opyt Dobychi Gaza (Theory and Practice of Gas Mining); Nedra: Moscow, Russia, 1998; p. 479.

45. Belonoshko, A.B.; Lukinov, T.; Rosengren, A.; Bryk, T.; Litasov, K.D. Synthesis of heavy hydrocarbons at the core-mantle boundary. Sci. Rep. 2015, 5, 18382. [CrossRef] [PubMed]

46. Dobretsov, N.L.; Koulakov, I.Y.; Litasov, Y.D. Migration paths of magma and fluids and lava compositions in Kamchatka. Russ. Geol. Geophys. 2012, 53, 1253-1275. [CrossRef] 